\title{
Response of Cotton to Potassium Levels Under Water Regime
}

\author{
Saad Flaih Hassan ${ }^{1}$, Shadha Abdulhasan Ahmed ${ }^{2}$, Layla Ismail Mohammed², \\ Musaab Abdulelah Yasir ${ }^{3}$ \\ ${ }^{1}$ Directorate of Agricultural Researches, Ministry of Agriculture, Baghdad, Iraq \\ ${ }^{2}$ College of Agriculture, University of Baghdad, Baghdad, Iraq \\ ${ }^{3}$ Ministry of Education, Vocational Education Directorate, Baghdad, Iraq
}

Email address:

saadflaih@yahoo.com (S. F. Hassan), shathaabdelhassan@yahoo.com (S. A. Ahmed), musaab09@yahoo.com (M. A. Yasir)

\section{To cite this article:}

Saad Flaih Hassan, Shadha Abdulhasan Ahmed, Layla Ismail Mohammed, Musaab Abdulelah Yasir. Response of Cotton to Potassium Levels Under Water Regime. International Journal of Applied Agricultural Sciences. Vol. 2, No. 4, 2016, pp. 56-63.

doi: $10.11648 /$ j.ijaas.20160204.13

Received: May 14, 2016; Accepted: June 3, 2016; Published: June 20, 2016

\begin{abstract}
A field trial was conducted at Experimental Field of Field Crop Department of College of Agriculture-Abu-Graib during 2011 and 2012 seasons to investigate the effect of potassium level in growth, lint yield and its components of cotton (Gossypium hirsutum L.) cultivar Lashata was grown under abundance and deficit water conditions. Split plot arrangement with randomized complete block design was used with three replicates. Irrigation intervals occupied main plots (Irrigation weekly and each two weeks) while potassium levels $\left(0,220,280,340,400 \mathrm{~kg} \mathrm{k}_{2} \mathrm{O}_{5} / \mathrm{ha}\right)$ occupied subplots. The statistical analysis showed superiority of irrigation at two weeks of seed cotton yield $(3.75 \mathrm{t} / \mathrm{h})$, number of open bolls per plant (20.47), number of sympodium per plant $(19.65$ and 17.27$)$, ginning percentage $(37.47)$ and water use efficiency $\left(0.38 \mathrm{~kg} / \mathrm{m}^{3}\right)$. There were significant effect of potassium in traits. The level $340 \mathrm{~kg} \mathrm{~K}_{2} \mathrm{O}_{5} /$ ha was gave the highest seed cotton yield (3.87 t/ha) due to attained the highest number of open bolls (29.25 bolls per plant for first season and gave $3.71 \mathrm{t} / \mathrm{ha}$ at $280 \mathrm{~kg} \mathrm{~K} \mathrm{O}_{5} / \mathrm{ha}$ due to higher boll weight $(3.57 \mathrm{~g})$ for second season. It could be conclude irrigation at two weeks with apply $280 \mathrm{~kg} \mathrm{~K}_{2} \mathrm{O}_{5} / \mathrm{ha} \mathrm{hadk}$ attained the highest seed cotton and ginning percentage to reduce water requirements of cotton in central region of Iraq.
\end{abstract}

Keywords: Irrigation Intervals, K, Seed Cotton Yield, WUE

\section{Introduction}

Generally the world agricultural production affected by environmental stresses which restricts the productivity of plant production to $50 \%$ of its potential [1], Just $10 \%$ from total world agricultural area that not faced stresses factors. Drought stress effecting growing and productivity is one of the most widespread environmental stresses exposed to the usable areas of the Earth up to $26 \%$ when classified in view of stress factors [2]. Due to drought condition simulate most physiological, biochemical and molecular responses, therefore plant developed its mechanisms to adapt to limited environment inputs, also drought consider the major factor for world geographical plant distribution and contribute of field crop development [3, 4]. Usually drought associated with raising temperature and radiation, therefore drought consider the most important environmental stresses, it is restricted survival, distribution and productivity of field crops, caused higher economic losses. Genetic potential change according to environmental factors such as water, fertilizer, temperature, day length (photoperiod) and solar radiation [5]. Cotton is the summer crop therefore can be improve its yield by use suitable management such as increase water use efficiency, but the limitation of water resources effect in growth and yield of world cotton.

The optimum levels of nutrients have play vital role in growth and yield of cotton under water deficit conditions especially in arid and semi-arid condition, however requirements of fertilizer become higher under irrigation compare with rainfall conditions. Potassium play important role in osmotic mechanisms and stomata conductance that important for plant water relationships and cell expansion [6]. Potassium one of the essential and important positive ion cytoplasm composition of higher plants, however its concentration reach to $80-150 \mathrm{Mm}$ [7], root uptake it from soil by active absorption [8], and moving to plant tissues. Although potassium have not construction in any part of plant but it has integrally involved in metabolism process 
water plant relationships and it has essential role in activation of many enzymes, has contribution in reaction for more than 60 enzymes [9] contribute in many biological processes in plant such as photosynthesis, respiration, carbohydrate synthesis, translocation and synthesis of proteins. The most importance function of potassium which maintains of osmotic potential and water absorption. Both functions are clear through regulation of stomata conductance [10, 11]. Cotton requirement of potassium is higher and sensitive to its deficit $[12,13]$. According to cotton productivity cotton uptake about $150 \mathrm{~kg} \mathrm{k}_{2} \mathrm{O} /$ ha from soil [14]. Although cotton own drought tolerance but when faced absence of soil moisture that could lead it to less absorption and translocation of nutrients. Yagmur [15] studied drought tolerance mechanisms for cotton cultivars under three water soil moisture, at full field capacity, $2 / 3$ and $1 / 3$ field capacity with different application levels of potassium (0, 100 and 200 $\mathrm{kg} \mathrm{k}_{2} \mathrm{O} / \mathrm{ha}$ ) caused decreased of plant height, bolls number and seed cotton yield with increase water stress, but percentage of first boll and ginning percentage were increased. Also potassium levels were affected significantly in plant height, bolls number, seed cotton yield, boll weight and ginning percentage. Xia et al [16] obtained significant differences in physiological and morphological traits such as plant height, number of squares and bolls number for two genotypes of cotton under water stress. Abood et al., [17] found about $100 \%$ of available water was gave highest yield but not differed from $80 \%$ level. Potassium had did impact significantly, the level $240 \mathrm{~kg} / \mathrm{ha}$ gave the highest yield but not differed from $480 \mathrm{~kg} / \mathrm{ha}$. The present study aimed to investigate of different potassium levels under two water intervals (weekly and at two weeks) in growth and seed cotton yield of cotton under the central region conditions of Iraq.

\section{Material and Methods}

A field trial was conducted at Experimental Field of Field Crops Department-College of Agriculture-Abu-Graib during 2011 and 2012. All field practices were done according to standard recommendations [18]. Seed of Lashata cultivar was sown at 4 and 8 April for 2011 and 2012 respectively. Split plot arrangement by randomized complete block design with three replicates was used, Irrigation intervals (weekly and at two weeks) occupied main plots while potassium levels of potassium $\left(0,220,280,340\right.$ and $400 \mathrm{~kg} \mathrm{~K}_{2} \mathrm{O}_{5} /$ ha occupied sub plots. The area of experimental unit was $12 \mathrm{~m}^{2}$, row length $4 \mathrm{~m}$, rows space $0.75 \mathrm{~m}$ and among plants $0.25 \mathrm{~m}$ with distances among replications $1 \mathrm{~m}$ and $3 \mathrm{~m}$ among irrigation intervals plots. Nitrogen fertilizer (urea $46 \% \mathrm{~N}$ ) was applied two times, firstly during sowing and second at emergence of first flower with average $184 \mathrm{~kg} \mathrm{~N} /$ ha. Phosphorus fertilizer applied of tricalcium phosphate with $249 \mathrm{~kg} / \mathrm{ha}$ after tillage. Water requirements applied according to cotton plant requirement (1000 mm/season) [19]. The total irrigation times reach to 20 times during season. Water counter was used for measuring quantity of applied water for each treatment. The EC of water was $1.9 \mathrm{dS} . \mathrm{m}^{-1}$ and $\mathrm{pH}$ 6.7. soil,

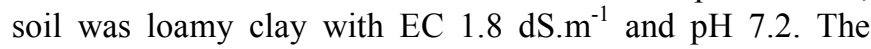
traits studied were plant height, number of monopodium, number of sympodium, number of total bolls, open bolls, average of boll weight, seed cotton yield, ginning percentage and water use efficiency (WUE):

WUE=Yield $(\mathrm{kg}) /$ Water applied $\left(\mathrm{m}^{3}\right)$ [20]

Statistical analysis was done and a means were compare by (1. s. d. 5\%).

\section{Results and Discussion}

\subsection{Plant Height}

Irrigation intervals and potassium levels were effected significantly in plant height (Table 1). It decreased from 153.93 to $126 \mathrm{~cm}$ with decreasing percentage about $18 \%$ at first season and 145.33 to $126.87 \mathrm{~cm}$ with decreasing percentage about $13 \%$ at second season with change irrigation intervals from two weeks to weekly. Can be show higher values of plant height at weekly irrigation due to water role that provide suitable conditions for all biological processes of plant to obtain increment in number and length of internodes to produce increment in longitudinal vegetative growth by activation of apical meristems and obtain the plant to main growth requirement which had attained higher values of plant height under water abundance condition. But under water deficit at two weeks irrigation interval had resulted decrement of available water and inhibition of cell division, expansion and decrease absorption of available water and translocation for these causes the conditions were had not suitable for growth, and decrease plant height due to water stress led to decrease of water potential for stem cells under critical limit for cell longitudinal and shortening internodes and recent plant height. This result agree with founds of other researchers such as Riahinia [21], Al-Khirllah [22], Yagmur et al., [15] and Abood et al., [17]. Associated potassium levels significant increment of plant height, it had increment from 113 to $156 \mathrm{~cm}$ with increment percentage about $28 \%$ in first season when increased potassium level from no potassium to $400 \mathrm{~kg} \mathrm{~K}_{2} \mathrm{O}_{5} / \mathrm{ha}$, and 104.5 to $156.33 \mathrm{~cm}$ with increment percentage about $33 \%$ when increased potassium level from no potassium to $340 \mathrm{~kg} \mathrm{~K}_{2} \mathrm{O}_{5} /$ ha at second season. Potassium one of importance common cation and commonly associated with many plant physiological processes such as photosynthesis, proteins synthesis, enzyme activity and water relationships of plant, it could be effect in growth development and delayed of leaf senescence [6], and then increasing plant height. Also potassium has play important role in cell division expansion and improve of plant hormones action which could be contribute directly in plant growth and reflect positively in plant height increasing [23]. Generally can be show that increasing potassium level had caused increasing plant height but there is an optimum level for potassium beyond it plant height became decreasing. Result were simulation with other result such as Abood et al., [17] and Yagmur et al., [15] they had pointed to superiority of potassium application compare with not application.

Significant interaction was obtained between irrigation intervals and potassium levels of plant height in both seasons. The highest value of plant height $(175$ and $165 \mathrm{~cm})$ were obtained at weekly irrigation and $400 \mathrm{~kg} \mathrm{~K}_{2} \mathrm{O}_{5} / \mathrm{ha}$, while less value $(101$ and $98.7 \mathrm{~cm})$ when irrigated at two week and zero 
potassium at first and second season respectively. Generally can be show increment of potassium levels was associated with positive response of plant height for each irrigation interval, Potassium increased of apical meristems ability to attain increasing plant growth especially at water scarcity condition. However that refer to importance of this vital nutrient in increasing plant growth and development which affected by water availability.

Table 1. Effect of irrigation intervals and potassium levels in plant height (cm).

\begin{tabular}{|c|c|c|c|c|c|c|}
\hline \multirow{2}{*}{$\begin{array}{l}2010 \\
\mathrm{~K}_{2} \mathrm{O} \text { (kg/ha) } \\
\end{array}$} & \multicolumn{6}{|c|}{2011} \\
\hline & Irrigation weekly & Irrigation at tow weeks & Mean & Irrigation weekly & Irrigation at tow weeks & Mean \\
\hline 0 & 125.00 & 101.00 & 113.00 & 110.33 & 98.67 & 104.50 \\
\hline 220 & 132.33 & 126.00 & 129.17 & 134.67 & 119.00 & 126.83 \\
\hline 280 & 167.67 & 129.00 & 148.33 & 152.67 & 128.67 & 140.67 \\
\hline 340 & 169.67 & 137.00 & 153.33 & 165.33 & 147.33 & 156.33 \\
\hline 400 & 175.0 & 137.00 & 156.00 & 163.67 & 140.07 & 152.17 \\
\hline 1. s. d $5 \%$ & 3.81 & & 2.14 & 5.73 & & 2.37 \\
\hline Mean & 153.93 & 126.00 & & 145.33 & 126.87 & \\
\hline 1. s. d $5 \%$ & 4.72 & & & 7.54 & & \\
\hline
\end{tabular}

\subsection{Number of Monopodium}

Irrigation intervals was not effected in number of monopodium at both seasons (Table 2). While had associated increasing potassium levels significant decrement of number monopodium per plant, it was decreased from 3.83 to 2.25 when increased potassium levels from zero to $280 \mathrm{~kg} / \mathrm{ha}$ with $7 \%$ decreasing percentage at first season, while at second season $340 \mathrm{~kg} / \mathrm{ha}$ gave less monopodium number (2.67) with $62 \%$ decreasing percentage compare with no potassium.

Table 2. Effect of irrigation intervals and potassium levels in number of monopodium per plant.

\begin{tabular}{|c|c|c|c|c|c|c|}
\hline \multicolumn{4}{|l|}{2010} & \multicolumn{3}{|l|}{2011} \\
\hline $\mathrm{K}_{2} \mathrm{O}$ (kg/ha) & Irrigation weekly & Irrigation at tow weeks & Mean & Irrigation weekly & Irrigation at tow weeks & Mean \\
\hline 0 & 5.33 & 2.33 & 3.83 & 4.33 & 4.33 & 4.33 \\
\hline 220 & 3.67 & 2.73 & 3.20 & 5.33 & 4.00 & 4.67 \\
\hline 280 & 2.33 & 2.17 & 2.25 & 3.67 & 2.67 & 3.67 \\
\hline 340 & 4.67 & 2.80 & 3.73 & 2.33 & 3.00 & 2.67 \\
\hline 400 & 3.33 & 2.93 & 3.13 & 4.33 & 3.67 & 4.00 \\
\hline 1. s. d $5 \%$ & 3.87 & & 0.55 & n. $\mathrm{s}$ & & 0.95 \\
\hline 1. s. d $5 \%$ & n. $\mathrm{s}$ & & & n. $\mathrm{s}$ & & \\
\hline
\end{tabular}

Generally can be show increasing potassium levels had associated with decreasing number of monopodium per plant. Potassium consider one of the most important nutrient by contribute in plant growth regulation through role in metabolism processes such as carbon synthesis, proteins synthesis, enzymes activity, cell and molecular systems of cell. It had play regulation role more than construction of plant life, its role appear clearly under drought stress condition, plant under this condition adapt to obtain balance between vegetative and reproductive growth. This result simulated with other researchers results such as Abood et al [17] and Yagumur et al., [15]. Significant interaction was obtained between irrigation intervals and potassium levels in number of monopodium per plant. The highest value was obtained (5.33 monopodium per plant) under weekly irrigation and zero potassium at first season while irrigation at two weeks and $220 \mathrm{~kg} \mathrm{~K}_{2} \mathrm{O}_{5} /$ ha with the highest value gave 5.33 monopodium per plant at second season. Can be show in this trail instable between increasing and decreasing under different irrigation intervals and potassium levels due to complex interaction of plant action mechanism under abundance deficit water with increasing potassium levels.

\subsection{Number of Sympodium}

Irrigation intervals and potassium levels were affected significantly of number of sympodium per plant (Table 3). Number of sympodium increased significantly at two week interval irrigation it gave 19.65 and 17.27 number of sympodium per plant compare with weekly irrigation that gave 15.35 and 14.4 number of sympodium per plant with 22 and $17 \%$ increasing percentage for first and second season respectively. Sympodium initiation and development consider one of the important criteria in cotton productivity, it was associated with increasing them which express of productivity plant potential to initiation and develop of squares those development at advance stages to open bolls. This result simulated with results of other researchers such as Soomro et al., [24], Oad et al., [25] and Al-Khirllah [22] but not agree with Abood et al., [17]. Number of sympodium increased with increasing potassium levels. It increased from 14.02 to 20.77 number of sympodium per plant with $32 \%$ increasing percentage at first season when increasing from no potassium to 280 and $\mathrm{f} 12$ to 18.5 sympodium per plant with increasing percentage $35 \%$ when increasing from no potassium to $340 \mathrm{~kg} \mathrm{~K} \mathrm{O}_{5} / \mathrm{ha}$ at second season. Potassium had contribution vital play in the most metabolic processes of plant such as carbon synthesis, Protein synthesis, enzymes activities and assimilates translocation of plant parts especially fruiting parts. Can be show that rapid increment of sympodium production with increasing potassium levels to critical level, beyond any excessive applied effect negatively and inhibition some plant metabolism. This result agree with found of Abood et al., [17].

Significant interaction was obtained between irrigation intervals and potassium levels of number of sympodium per 
plant, the highest number (24.77) had obtained at two weeks irrigation and $280 \mathrm{~kg} \mathrm{~K}_{2} \mathrm{O}_{5} /$ ha at first season and 20.67 under two weeks irrigation with $340 \mathrm{~kg} \mathrm{~K}_{2} \mathrm{O}_{5}$ /ha at second season. That role due to positive response of potassium in somatic adjustment and regulation of water potential in plant through stomata conductance. Therefore potassium application consider one of easy and important strategically ways to face problems of water deficit and scarcity.

Table 3. Effect of irrigation intervals and potassium levels in number of sympodium per plant.

\begin{tabular}{|c|c|c|c|c|c|c|}
\hline \multicolumn{4}{|l|}{2010} & \multicolumn{3}{|l|}{2011} \\
\hline $\mathrm{K}_{2} \mathrm{O}$ (kg/ha) & Irrigation weekly & Irrigation at tow weeks & Mean & Irrigation weekly & Irrigation at tow weeks & Mean \\
\hline 0 & 12.93 & 15.10 & 14.02 & 12.33 & 11.67 & 12.00 \\
\hline 220 & 14.77 & 18.77 & 16.77 & 14.67 & 15.00 & 14.83 \\
\hline 280 & 15.77 & 24.77 & 20.77 & 13.33 & 20.33 & 16.83 \\
\hline 340 & 17.60 & 20.77 & 19.18 & 16.33 & 20.67 & 18.50 \\
\hline 400 & 15.67 & 18.83 & 17.25 & 15.33 & 18.67 & 17.00 \\
\hline 1. s. d $5 \%$ & 1.98 & & 1.42 & 1.87 & & 1.46 \\
\hline Mean & 15.35 & 19.65 & & 14.4 & 17.27 & \\
\hline 1. s. d $5 \%$ & 1.74 & & & 0.76 & & \\
\hline
\end{tabular}

\subsection{Number of Total Bolls Per Plant}

Statistical analysis refer to not effect of irrigation intervals in number of total bolls in both seasons (Table 4). While increasing potassium levels had associated with significantly increasing in both seasons, which increased from 28.83 to 36.17 bolls with increasing percentage about $20 \%$ when increasing potassium levels from zero to $280 \mathrm{~kg} \mathrm{~K}_{2} \mathrm{O}_{5} /$ ha but decreased beyond this level at first season, and increased from 17.5 to 25.5 bolls per plant with increasing percentage about $31 \%$ when increasing potassium level from zero to 340 $\mathrm{kg} \mathrm{K}_{2} \mathrm{O}_{5} /$ ha but did not differ significantly from 280 and 400 $\mathrm{kg} \mathrm{K}_{2} \mathrm{O}_{5} /$ ha at second season.

Table 4. Effect of irrigation intervals and potassium levels in number of total bolls per plant.

\begin{tabular}{lllllll}
\hline $\mathbf{2 0 1 0}$ & & & $\mathbf{2 0 1 1}$ & & \\
\hline $\mathbf{K}_{\mathbf{2}} \mathbf{O}(\mathbf{k g} / \mathbf{h a})$ & Irrigation weekly & Irrigation at tow weeks & Mean & Irrigation weekly & Irrigation at tow weeks & Mean \\
\hline 0 & 29.33 & 28.33 & 28.83 & 17.33 & 17.67 & 22.67 \\
220 & 27.67 & 27.67 & 27.67 & 22.67 & 26.50 & 2.67 \\
280 & 32.00 & 40.33 & 36.17 & 26.67 & 23.50 & 25.50 \\
340 & 27.00 & 31.33 & 29.17 & 25.33 & 24.00 & 23.50 \\
400 & 27.00 & 25.33 & 26.17 & 23.00 & & \\
1. s. d 5\% & 3.11 & & 1.93 & n. s & \\
Mean & 28.6 & 30.6 & & 23.00 & 23.27 & \\
1. s. d 5\% & n. s & & n. s & & \\
\hline
\end{tabular}

That may be due to the important role of potassium in the most biological metabolism, proteins synthesis and increasing enzymes activities they related with growth and developmental reproductive stages from initiation of buds, flowering, fertilization, growth and development of boll. Can be show that an optimum potassium level had attained optimum bolls number beyond it decreased. Significant interaction was obtained between irrigation intervals and potassium levels at first season. The highest bolls number (40.33 bolls) was obtained at two week irrigation interval and $280 \mathrm{~kg} / \mathrm{ha}$ of potassium, while less number (25.33 boll per plant) had attained under same irrigation interval and $400 \mathrm{~kg} \mathrm{~K}_{2} \mathrm{O}_{5} /$ ha.

\subsection{Number of Open Bolls Per Plant}

Irrigation intervals were effected significantly at second season while potassium levels effected significantly at both seasons in number of open bolls per plant (Table 5). The highest number was reached at two week irrigation interval, while decreased at weekly irrigation from 20.47 to 18.8 open bolls at second season. Decreasing number of open boll had caused by decreasing total boll number (Table 4). Can be explained increasing open boll under deficit irrigation to attain optimum growth and little shedding. This result was simulated with results of other researchers such as Soomro et al., [24], Onder et al., [26] and Al-Khirllah [22], they found cotton plant had higher ability to adapt under water stresses conditions, while didn't agree with Elian [27] and Alishah and Ahmedkhan [28] they found number of bolls produced under stresses condition less compare with an optimum conditions.

Table 5. Effect of irrigation intervals and potassium levels of cotton in number of open bolls per plant.

\begin{tabular}{|c|c|c|c|c|c|c|}
\hline \multicolumn{4}{|l|}{2010} & \multicolumn{3}{|l|}{2011} \\
\hline $\mathrm{K}_{2} \mathrm{O}$ (kg/ha) & Irrigation weekly & Irrigation at tow weeks & Mean & Irrigation weekly & Irrigation at tow weeks & Mean \\
\hline 0 & 22.67 & 22.52 & 22.59 & 13.33 & 16.33 & 14.83 \\
\hline 220 & 22.93 & 25.33 & 24.13 & 17.33 & 19.00 & 18.17 \\
\hline 280 & 24.83 & 33.67 & 29.25 & 23.33 & 25.33 & 24.33 \\
\hline 340 & 23.43 & 26.67 & 25.05 & 21.67 & 23.33 & 22.50 \\
\hline 400 & 22.60 & 16.93 & 19.77 & 18.33 & 18.33 & 18.33 \\
\hline 1. s. d $5 \%$ & 2.61 & & 1.53 & n. $\mathrm{s}$ & & 2.06 \\
\hline 1. s. d $5 \%$ & n. $s$ & & & 0.76 & & \\
\hline
\end{tabular}


Potassium levels were effected significantly in number of open bolls, it increased from 22.59 to 29.25 open bolls per plant with $23 \%$ increasing percentage at first season also increased from 14.83 to 24.33 open bolls with $39 \%$ increasing percentage when increased potassium level from zero to $280 \mathrm{~kg} \mathrm{~K} \mathrm{O}_{5} /$ ha at second season. Can be show obtained gradually decrement in open bolls with increased potassium level from optimum level. Increasing open bolls with increasing potassium level because its impact in most biological and metabolic processes of plant, it was effected in growth and develop of boll which reflected in produced more open boll which contribute in lint yield. This result simulated with Yagmur et al., [15] they obtained the highest open bolls was attined at $100 \mathrm{~kg} \mathrm{~K} \mathrm{~K}_{2} \mathrm{O} / \mathrm{ha}$. Significant interaction was obtained between irrigation intervals and potassium level in number of open bolls at first season. The highest value (33.67) at two week interval with $280 \mathrm{~kg} \mathrm{~K}_{2} \mathrm{O}_{5} /$ ha while less value (16.93) at same irrigation interval with $400 \mathrm{Kg}$ $\mathrm{K}_{2} \mathrm{O}_{5} /$ ha.

\subsection{Boll Weight}

Irrigation intervals and potassium level were effected significantly in boll weight (Table 6). Weekly interval irrigation was gave the highest value about 4.00 and $3.56 \mathrm{~g}$ while two weeks interval gave less value about 3.49 and $3.41 \mathrm{~g}$ with increasing percentage 13 and $4 \%$ for first and second seasons respectively. Decreasing boll weight under water stress belong to deficit of assimilates especially during reproductive stage which led to decreasing boll weight and increasing total bolls and open bolls number per plant (Table 4 and 5) associated decrement boll weight as a compensation relationship. Some other researchers found similar results such as Mahmood [29], Ondero et al., [26] and Al-Khirllah [22], while Mutar [30] referred irrigation at two weeks interval was appeared superior performance compare with other treatment in this trait.

Table 6. Effect of irrigation intervals and potassium levels in boll weight (g).

\begin{tabular}{|c|c|c|c|c|c|c|}
\hline \multicolumn{4}{|l|}{2010} & \multicolumn{3}{|l|}{2011} \\
\hline $\mathrm{K}_{2} \mathrm{O}$ (kg/ha) & Irrigation weekly & Irrigation at tow weeks & Mean & Irrigation weekly & Irrigation at tow weeks & Mean \\
\hline 0 & 3.13 & 3.08 & 3.11 & 3.20 & 2.97 & 3.08 \\
\hline 220 & 3.67 & 3.10 & 3.39 & 3.93 & 3.23 & 3.58 \\
\hline 280 & 3.43 & 3.20 & 3.32 & 3.67 & 3.47 & 3.57 \\
\hline 340 & 4.57 & 4.16 & 4.37 & 3.67 & 3.73 & 3.70 \\
\hline 400 & 3.68 & 3.89 & 3.79 & 3.31 & 3.63 & 3.47 \\
\hline 1. s. d $5 \%$ & 0.17 & & 0.13 & 0.30 & & 0.23 \\
\hline 1. s. d $5 \%$ & 0.02 & & & 0.13 & & \\
\hline
\end{tabular}

Potassium levels were effected significantly in boll weight. The highest value for boll weight about $4.37 \mathrm{~g}$ at $340 \mathrm{~kg}$ $\mathrm{K}_{2} \mathrm{O}_{5} /$ ha with $29 \%$ increasing percentage compare with no potassium in first season also same level gave the highest value about $3.70 \mathrm{gm}$ with increasing percentage about $17 \%$ at second season compare with no potassium. Can be show the important and clearly effect of potassium in increasing boll weight, these belong to essential role of potassium in most metabolism processes growth and reproductive development that reflected positively in boll weight. Clearly there was the optimum level of potassium to obtain increment in boll weight, beyond after was did decrement with increasing potassium level.

Significant interaction between irrigation intervals and potassium levels for boll weight was recorded. Highly value was obtained (4.57g) at weekly irrigation with $340 \mathrm{~kg} \mathrm{~K}_{2} \mathrm{O}_{5} /$ ha for first season and 3.93g under weekly irrigation interval and $220 \mathrm{~kg} \mathrm{~K}_{2} \mathrm{O}_{5} /$ ha potassium level at second season.

\subsection{Seed Cotton Yield}

Seed cotton yield was affected significantly by irrigation intervals at first season and potassium levels for both seasons (Table 7). Seed cotton yield was increased from 3.31 to 3.75 $\mathrm{t} / \mathrm{ha}$ at two weeks irrigation interval with $12 \%$ increasing percentage. Seed cotton yield was increased due to increased sympodium number (Table 3), total bolls number (Table 4) and number of open bolls (Table 5).

Table 7. Effect of irrigation intervals and potassium levels in seed cotton yield (t/ha).

\begin{tabular}{lllllll}
\hline $\mathbf{2 0 1 0}$ & & & $\mathbf{2 0 1 1}$ & \\
\hline $\mathbf{K}_{\mathbf{2}} \mathbf{O}(\mathbf{k g} / \mathbf{h a})$ & Irrigation weekly & Irrigation at tow weeks & Mean & Irrigation weekly & Irrigation at tow weeks & Mean \\
\hline 0 & 2.92 & 3.08 & 2.97 & 2.17 & 1.99 & 2.08 \\
220 & 3.41 & 3.48 & 3.45 & 2.63 & 2.51 & 2.57 \\
280 & 3.68 & 3.59 & 3.64 & 3.61 & 3.80 & 3.71 \\
340 & 3.34 & 4.39 & 3.87 & 3.25 & 3.11 & 3.27 \\
400 & 3.22 & 4.21 & 3.72 & 2.72 & & 2.92 \\
1. s. d 5\% & 0.21 & & 0.16 & 0.18 & 2.94 & \\
Mean & 3.31 & 3.75 & & 2.88 & & \\
1. s. d 5\% & 0.12 & & & n. s & \\
\hline
\end{tabular}

Excessive irrigation led to increased number of monopodium number (Table 2) however it decreased of reproductive growth, while at two weeks interval was happened inverse. Therefore increase irrigation interval 
consider one of the important strategic way of plant to turn to reproductive growth moreover decrease of water quantities. This result agree with Mutar [30], Oad [25] and Al-Khirllah [22], while did not agree with results of Honey [31], Siddiqui et al., [32], Hameed and Abood [33] and Abood et al., [17]. Potassium levels were effected significantly in seed cotton yield. The highest value $(3.87 \mathrm{t} / \mathrm{ha})$ with $23 \%$ increasing percentage when increasing from 0 to $340 \mathrm{~kg} \mathrm{~K}_{2} \mathrm{O}_{5} /$ ha at first season and $3.71 \mathrm{t} /$ ha by increasing to $280 \mathrm{~kg} \mathrm{~K}_{2} \mathrm{O}_{5} /$ ha with $44 \%$ increasing percentage. Increasing seed cotton yield by increasing potassium level attribute to increasing sympodium (Table 3) and total boll number (Table 4) and open boll number (Table 5) with increasing $3.8 \mathrm{t} /$ ha for second season.

Generally can be show that increasing potassium level was associated significant increasing seed cotton yield under two weeks irrigation and the optimum potassium level ranged from 280-340 $\mathrm{kg} \mathrm{K} \mathrm{K}_{2} \mathrm{O}_{5} /$ ha. Potassium consider one of the important nutrient that own effect direct or indirect in vegetative and reproductive growth which reflected positively in seed cotton yield directly. Abood et al., [17] did not obtained same result trend while Yagmur et al., [15] obtained the highest seed cotton yield at $100 \mathrm{~kg} \mathrm{k}_{2} \mathrm{O}_{5} / \mathrm{ha}$. significant interaction was attained between irrigation intervals and potassium levels for seed cotton yield. Irrigation at two weeks and $340 \mathrm{~kg} \mathrm{k}_{2} \mathrm{O}_{5}$ /ha was obtained the highest seed cotton yield about 4.39 ton/ha which did not differed from same irrigation interval but $400 \mathrm{~kg} \mathrm{k}_{2} \mathrm{O}_{5} /$ ha gave $(4.21 \mathrm{t} / \mathrm{ha})$ at first season, while irrigation at two weeks and $280 \mathrm{~kg} \mathrm{k}_{2} \mathrm{O}_{5} /$ ha was attained the highest seed cotton yield about $3.8 \mathrm{t} / \mathrm{ha}$ at second season. Generally can be show increasing potassium level had associated significant increasing seed cotton yield under two weeks irrigation and the optimum potassium level ranged from $280-340 \mathrm{~kg}$ $\mathrm{K}_{2} \mathrm{O}_{5} /$ ha.

\subsection{Ginning Percentage}

Irrigation intervals and potassium levels were effected significantly in ginning percentage (Table 8). Ginning percentage was increased significantly from 31.8 to 37.47 with $15 \%$ increasing percentage at two weeks interval irrigation at first season. Increasing ginning percentage with increasing irrigation interval attribute to increasing seed cotton yield (Table 7). Muttar [30] and Al-Khirllah [22] obtained same results, that two weekly irrigation interval gave the highest ginning percentage about $21.14 \%$. But Lee et al., [34], Honey [31] and Sahito et al., [35] were found irrigation at 21 days (three weeks) had attained the highest ginning percentage about $33.86 \%$. Associated increasing potassium levels significant increment of ginning percentage in both seasons. It was reached the highest value $(39.5 \%)$ with $19 \%$ increasing percentage at $280 \mathrm{~kg} \mathrm{~K}_{2} \mathrm{O}_{5} /$ ha compare with no potassium at first season and $42.5 \%$ with $15 \%$ increasing percentage but did not differ significantly with $340 \mathrm{~kg} \mathrm{~K} \mathrm{~K}_{2} \mathrm{O}_{5} / \mathrm{ha}(41.33 \%)$ at second season. Increasing ginning percentage with increasing potassium level attribute to increasing seed cotton yield (Table 7). Yagmur et al., [15] he found that applied $100 \mathrm{~kg} \mathrm{~K}_{2} \mathrm{O}_{5} /$ ha was gave the highest ginning percentage. Significant interaction was attained between irrigation interval and potassium levels at first season. The highest ginning percentage (43.67\%) was obtained under two weeks intervals with $280 \mathrm{~kg} \mathrm{~K} \mathrm{O}_{5} / \mathrm{ha}$. Can be show clearly increasing potassium levels attained increasing of ginning percentage at each irrigation interval, it refer to importance rolr of potassium especially under irrigation regime to increasing ginning percentage, therefore could be consider potassium application one of active strategic to increasing ginning percentage.

Table 8. Effect of irrigation intervals and potassium levels in ginning percentage.

\begin{tabular}{lllllll}
\hline $\mathbf{2 0 1 0}$ & & & $\mathbf{2 0 1 1}$ & & \\
\hline $\mathbf{K}_{\mathbf{2}} \mathbf{O}(\mathbf{k g} / \mathbf{h a})$ & Irrigation weekly & Irrigation at tow weeks & Mean & Irrigation weekly & Irrigation at tow weeks & Mean \\
\hline 0 & 31.00 & 32.67 & 31.83 & 36.00 & 36.33 & 36.17 \\
220 & 31.67 & 38.33 & 35.00 & 38.67 & 38.67 & 38.67 \\
280 & 35.33 & 43.67 & 39.50 & 41.33 & 43.67 & 42.50 \\
340 & 29.67 & 34.33 & 32.00 & 41.33 & 41.33 & 31.33 \\
400 & 31.33 & 38.33 & 34.83 & 37.33 & 37.33 & 2.33 \\
1. s. d 5\% & 3.20 & & 1.92 & n. s & & \\
Mean & 31.8 & 37.47 & & 38.93 & 39.47 & \\
1. s. d 5\% & 3.80 & & & n. s & & \\
\hline
\end{tabular}

\subsection{Water Use Efficiency (WUE)}

Table 9. Effect of irrigation intervals and potassium levels in water use efficiency (WUE) $\left(\mathrm{kg} / \mathrm{m}^{3}\right)$.

\begin{tabular}{|c|c|c|c|c|c|c|}
\hline \multicolumn{4}{|l|}{2010} & \multicolumn{3}{|l|}{2011} \\
\hline $\mathrm{K}_{2} \mathrm{O}(\mathrm{kg} / \mathrm{ha})$ & Irrigation weekly & Irrigation at tow weeks & Mean & Irrigation weekly & Irrigation at tow weeks & Mean \\
\hline 0 & 0.22 & 0.20 & 0.21 & 0.29 & 0.31 & 0.30 \\
\hline 220 & 0.26 & 0.25 & 0.26 & 0.34 & 0.35 & 0.35 \\
\hline 280 & 0.36 & 0.38 & 0.37 & 0.37 & 0.37 & 0.36 \\
\hline 340 & 0.33 & 0.32 & 0.33 & 0.33 & 0.44 & 0.39 \\
\hline 400 & 0.27 & 0.31 & 0.29 & 0.32 & 0.42 & 0.37 \\
\hline 1. s. d $5 \%$ & 0.12 & & 0.01 & 0.02 & & 0.01 \\
\hline Mean & 0.29 & 0.29 & & 0.33 & 0.38 & \\
\hline 1. s. d $5 \%$ & n. $\mathrm{s}$ & & & 0.2 & & \\
\hline
\end{tabular}


WUE was affected significantly by irrigation intervals and potassium levels (Table 9). It was increased significantly from 0.33 to 0.38 with $15 \%$ increasing percentage at two weeks irrigation interval at second season. This increment attributed to increasing seed cotton yield (Table 7). This result agree with Mutar [30] that WUE can be increased with decreasing irrigation times, also Al-Khirllah [22] reported that irrigation at each two weeks was gave superior result which gave WUE $1.11 \mathrm{~kg} / \mathrm{m} 3$ by decreasing water quantity. The primary plant response to water deficit include partial or complete stomata enclosure to attain decreasing evapotranspiration and improve WUE $[36,37]$. On the other hand can be explain decreasing WUE at control treatment attribute to increasing water quantity compare with its yield produced, Some other researchers found similar results such as Fusheing [38], and Wang at el [37].

Potassium levels were effected significantly in WUE compare with no potassium. It was reached to $0.37 \mathrm{~kg} / \mathrm{m}^{3}$ with $43 \%$ increasing percentage under $280 \mathrm{~kg} \mathrm{~K}_{2} \mathrm{O}_{5} / \mathrm{ha}$ at first season and $0.39 \mathrm{~kg} / \mathrm{m}^{3}$ with $23 \%$ increasing percentage under $340 \mathrm{~kg} \mathrm{~K} \mathrm{~K}_{5} / \mathrm{ha}$ at second season. Potassium stimulate root growth and water absorption moreover it decrease soil moisture losses by decreasing evapotranspiration and increase plant water keeping ability and recently increasing WUE [39]. Can be show clearly that WUE tend to increasing with increasing potassium levels, that refer and certain the important role of potassium application in the physiological and biochemical plant processes especially in regulation of stomata conductivity and water absorption which reflected positively in WUE [40].

Significant interaction was obtained between irrigation intervals and potassium levels in WUE, it was reach the highest value $0.38 \mathrm{~kg} / \mathrm{m}^{3}$ under two week interval irrigation with $280 \mathrm{~kg} \mathrm{~K} \mathrm{O}_{5} /$ ha at first season and $0.44 \mathrm{~kg} / \mathrm{m}^{3}$ at same irrigation interval and $340 \mathrm{~kg} \mathrm{~K}_{2} \mathrm{O}_{5} / \mathrm{ha}$ at second season. Generally can be show that increasing potassium level was associated rapidly increment in WUE at each irrigation interval and was reached climax value at $280-340 \mathrm{~kg} \mathrm{~K} \mathrm{O}_{5} /$ ha. That refer to importance of potassium application especially under water regime, it seem the highest values were attained under two week irrigation interval.

Recently can be conclude irrigation at two weeks one of the important strategic way to attain the highest seed cotton and ginning percentage which mean decreasing water irrigation quantity to half and exploitation in cultivation cotton in much areas, especially cotton consider summer crop and water one of critical factors in growing and production. Increasing potassium level to $280 \mathrm{~kg} / \mathrm{ha}$ was attained the highest seed cotton and ginning percentage but any increasing potassium level be not economic due to the highest cost value of fertilizer, so that can be recommend to applied $280 \mathrm{~kg} \mathrm{~K}_{2} \mathrm{O}_{5} /$ ha under two week irrigation interval to attain the highest seed cotton and ginning percentage for Lashata cultivar cotton at central region condition of Iraq.

\section{References}

[1] Boyer, J. S. 1982. Plant productivity and environment. Science. 218: 443-448.
[2] Blum, A. 1986. Breeding crop varieties for stress environments. Crit. Rev. Plant Sci. 2: 199-237.

[3] Flexas, J., J. M. Escalona, H. Medrano, 1999. Water stress induces different levels of photosynthesis and electron transport rate regulation in grapevines. Plant Cell Environ. 22: 39-48.

[4] Schulze, E. D. 1986. Carbon dioxide and water vapor response to drought in the atmosphere and in the soil. Annu. Rev. Plant Phys., 37: 247-274.

[5] Bradow, J. M., Davidonis, G. H. 2000. Quantitative of fibre quality and the cotton production-processing interface: A physiologist's perspective. J. Cotton Sci. 4: 34-64.

[6] Pettigrew, W, T. 2008. Potassium influences on yield and quality production for maize, wheat, soybean and cotton. physiologia plantarum (131): 670-681.

[7] Blevins, D. G. 1985. Role of protein in protein metabolism in plants. pp. 413-424. In Potassium in Agriculture. American Society of Agronomy, Madison, Wisconsin.

[8] Hoagland, D. R. 1948. Lectures on the inorganic nutrition of plants. Chronica Botanica Waltham, Massachusetts. pp. 48-71.

[9] Evans, H. J. and G. J. Sorger, 1966. Role of mineral elements with emphasis on univalent cations. Annual Review of Plant Physiology 17: 47-76.

[10] Humble, G. D. and Raschke, K. 1971. Stomatal opening quantitatively related to potassium transport. Plant Physiology, 48: 447-453.

[11] Epstein, E. 1972. Mineral nutrition of plants: Principles and perspectives. Wiley, New York.

[12] Cassman, K. G., Roberts, B. A. Kerby, T. A. Bryant, D. C. and D. C. Higashi, D. C. 1989. Soil potassium balance and cumulative cotton response to annual potassium additions on a vermiculitic soil. Soil Science Society of America Journal 53: 805-812.

[13] Adeli, A., and J. J. Varco, 2002. Potassium management effects on cotton yield, nutrition, and soil potassium level. J. Plant Nutr. 2, 2229-2242.

[14] Saparov, A., Eleshev, R., Suleimenov, B., Peskovki, G., Shcherbakov, A. 2013. Effect of Potassium Chloride Application for Rice, Cotton and Potato in the Irrigated Zone of Kazakhstan. Better Crops with Plant Food. 97, 23-25.

[15] Yagmur, B., A. Gurel, Y. Oren, B. Izci, A. Edreva, H. Hakerlerler, S. Hayta, H. Akdemir and L. Yildiz-Aktas. 2014. Effect of different drought applications and potassium doses on cotton yield and fiber quality. J. Agric. and Environ. Management. 3 (1): 60-67.

[16] Xia, Y., Jiang, C. C., Chen, F., Lu, J. W., Wang, Y. H. 2011. Differences in growth and potassium use efficiency of two cotton genotypes. Commun. Soil Sci. Plant Anal. 42, 132-143.

[17] Abood, M. A., O. A. Ahmed and A. S. Mehdi. 2014. Effect of potassium fertilizer, deficit irrigation and organic matter on cotton tolerance to drought. Dyalla J. of Agric. Sci. 6 (1): 202214.

[18] Mohammed, L. I. 2011. Cotton: from growing to ginning. Technical Bulletin. State Board of Agricultural Extension and cooperation-Ministry of Agriculture.

[19] Kwaiz, G. M., S. Abdulsattar and D. S. Bea. 1977. Index of Crop irrigation at central region of Iraq Unit of water requirement researches. 
[20] Altaeef, N. I. and I. K. Alhadathy. 1988. Irrigation Principles and its applications. Minsitry of Higher education and Scientific Research. University of Baghdad. Pp: 434.

[21] Riahinia, S. H. 2003. Evaluation of water stress in corn, sunflower, Cotton and bean. M. Sc. thesis of Agronomy, Faculty of Agriculture, Ferdowsi University of Mashhad.

[22] Al-Khirllah, M. A. Y. 2012. Response of some cotton varieties and hybrids consulted for two irrigation. A thesis. College of Agric. Univ. of Baghdad.

[23] Essa, T. A. 1990. Physiology of Crop Plants. Ministry of Higher Education and Scientific Research. University of Baghdad (Translated).

[24] Soomro, A. R. 2000. Heterosis studies in intraspecific crosses of Gossypium hirsutum L. J. of Scientific and Industrial Research. 43 (6): 363-366.

[25] Oad, F. C., A. A. Lakho, A. Soomro, N. L. Oad, G. Q. Chandio, and Z. A. Abro. 2001. Partial economic analysis of cotton for water saving and potential yield. Pakistan Journal of Applied Sci. 1 (3): 335-336.

[26] Onder, D., Y. Akiscan, S. Onder and M. Mert. 2009. Effect of different irrigation water level on cotton yield and yield components. African Journal of Biotechnology 8 (8): 15361544 .

[27] Elian, B. j. 2002. An integrated expert system for cotton irrigation scheduling. Transaction at the American Society of Agricultural Engineers. 53: 1722-1729.

[28] Alishah, O. and A. Ahmadikhah. 2009. The effect of drought stress on improved cotton varieties in golesatn province of Iran. International Journal of Plant Production. 3 (1): 17-26.

[29] Mahmood, Y. N. 2004. Response of some cotton genotypes (Gossypium hirsutum L.) for different irrigation interval after flowering. M. Sc. thesis. College of Agriculture. University of Tikrit.

[30] Mutar, H. K. A. 1985. Effect of irrigation interval and plant density on lint yield and quality for cocker 310 cotton variety. M. Sc. thesis. College of Agriculture, University of Baghdad.
[31] Honey, B. J. 2003. Impact of quality on the profitability of irrigated cotton production on the Texas height plains. National Cotton. J. (1): 216-222.

[32] Siddiqui, M. H., F. C. Oad and U. A. Buriro. 2007. Response of cotton cultivars to varying irrigation regimes. Asian Journal of Plant Sci. 6 (1): 153-157.

[33] Hameed, R. M. and M. A. Abood. 2010. Effect of irrigation intervals after flowering and nitrogen fertilizer in growth and yield of cotton (Gossypium hirsutum L.). Journal of Daylia Agricultural Science. 2 (2): 177-186.

[34] Lee, Y. Sh. 2003. Improving water use efficiency of irrigated crops in the north China. Indian. J. 88: 272-298.

[35] Sahito, A., Z. A. Baloch, A. Mahau, S. A. Otho, S. A. Kalhoro, A. Ali, F. A. Kalhoro, R. N. Soomro and F. Ali. 2015. Effect of water stress on the growth and yield of cotton crop (Gossypium hirsutum L.). American Journal of Plant Siences, 6: 1027-1039.

[36] Waseem, M., A. Ali, M. Tahir, M. A. Nadeem, M. Ayub, A. Tanveer, R. Ahmad and M. Hussain. 2011. Mechanism of drought tolerance in plant and its management through different methods. Continental J. Agric. Sci. 5 (1): 10-25.

[37] Wang, X., I. Mohamed, Y. Xia and F. Chen. 2014. Effect of water and potassium stress on potassium utilization efficiency of two cotton genotypes. J. of Soil Sci. and Plant Nutrition. 14 (4): $833-844$.

[38] Fusheing, L. 2006. Potassium and water interaction. International Work Shop Soil Potassium and K Fertilizer Management. Agric. Coll. Guangxi Univ. 1-32.

[39] Umar, S. 2006. Alleviating adverse effects of water stress on yield of sorghum, mustard and groundnut by potassium application. Pak. J. Bot., 38 (5): 1373-1380.

[40] Gonzalez, M. B., O. Arquero, J. M. Fournier, D. Barranon and M. Benlloch. 2007. K-starvation inhibits water stress induced stomatal clousure. J. of Plant Physiology. 165 (6): 623-630. 